\title{
The Complex Construction of Female English Teachers' Identity in Iran
}

\author{
Fakhereh Safatian (Corresponding author) \\ Department of foreign languages, Kharazmi University \\ No.43. South Mofatteh Ave. Tehran, Iran
}

Received: May 30, 2020 Accepted: July 1, 2020 Published: July 5, 2020

doi:10.5296/jsel.v8i1.17312ＵRL: https://doi.org/10.5296/jsel.v8i1.17312

\begin{abstract}
There has been a growing interest regarding the identity formation in the broader TESOL research field; however there is scares number of studies which examined the formation of the female teacher's identity using a feminist poststructuralist framework. This study also attempts to help to grow the existing literature regarding the female teacher's identity formation by seeking to explore the construction of an Iranian female English teacher identity and the related discourses that shape and reshape her identity through delving into the narratives, using data collected from interviews. To investigate the participant's main subject positions and the prevailing discursive practices that construct them, feminist poststructuralist conceptual framework was applied in this study. The research data, gathered from interviews indicates the teacher's identity as multiple, complex, and contradictory construct. The findings reveal both gender and professional discourses impact the way which this woman tries to conceive a sense of coherent self. The normative, disciplinary, and individualizing nature of the gender and professional discourses was also revealed as the result of the analysis.
\end{abstract}

Keywords: Identity, EFL teacher, Narratives, Feminist poststructuralist framework

\section{Introduction}

Iranian female English teacher's perception of her and her sense of identity is being explored in this study. The study investigates the ways in which this female English teacher in Iranian higher education defines, interpret, and constitute her identity. This examination centers on the work of self-investigation, redefinition, and adjustment that the participant of the study experience on a regular premise, Based on the members individual records and encounters of family, public activity, instruction, and occupation. It involves extraordinary significance to recollect that these moves do not occur in a vacuum. Her social settings including her 
educational experiences work as the social locales of dynamic battle over domineering discourses, morals, and practices which continually intercede her life (Aisenberg and Harrington, 1988; Stromquist, 1995; Walker, 1998). Being arranged at the junction of various opposing discourses, for example, those identified with Iranian conventional and nearby societies, the ideological discourse of the state, and the mounting impact of the Western societies, this female English teacher battle to situate herself inside, between and against the different predominant discourses in the Iranian setting. Utilizing a Foucauldian-women's activist methodology, this investigation endeavors to concentrate on the manners by which sexual orientation disciplinary forces and systems of truth make female subjects and regularizing femininity. I additionally mean to concentrate on the expert discourses identified with the development of good English instructor that target making inflexible personality openings or subject positions. By breaking down the meeting accounts as the impacts of desultory practices, I mean to investigate how this present woman character is intervened through discourses (Weedon, 1987; St Pierre and Pillow, 2000; Alldred and Gillies, 2002). I likewise attempt to exhibit the dynamic battle of the current opposing discourses over authority and the manners by which these discourses endeavor to shape, characterize and recreate female subjects. In this light, the investigation ought to be seen as a miniaturized scale examination of the entangled procedure of character development that this member experience every day; an investigation of the continuous battle that she faces in making and reproducing selves inside these clashing verbose limits.

I decided to look at this specific theme for my examination for certain reasons. First, essential objectives of this examination is to give the setting to the too-long unheard voice of this woman who experience, on an everyday premise, numerous types of mastery yet steadily endeavor to make due inside an incredibly unpredictable trap of social and ideological powers that try to control and keep up her subjected position. This examination attempts to offer voice to this disparaged and unattended encounters and tries, just as to depict a portion of the difficulties, logical inconsistencies and quandaries that this female instructor needs to experience in her endeavor to establish her character in Iran.

This exploration work likewise targets permitting the participant of this study's voice to resound with other female instructors' encounters and empower women, teachers and language educators who will peruse this investigation to see their own lives reflected in these accounts. Subsequently, there is the likelihood that we as a whole could think about this woman's accounts of battles, disappointments, and achievements, and maybe relate to her. At last, it is additionally the situation that next to no exploration consideration has been coordinated to the issue of the development of female character in Iranian advanced education. The way that there has been deficient collection of exploration especially with respect to ELT instructors' personality arrangement in Iran set off concentrating how female teachers approach the mind boggling procedure of making and reproducing a feeling of self.

\section{Literature Review}

\subsection{Dual Position of Women in Iran}




\section{MInstitute ${ }_{\text {Math }}^{\text {Macrothink }}$}

The motivation behind this segment is to show the various discourses and force relations that encompass women in a nation which is ensnared in a double culture of - tradition from one viewpoint, and - modernity on the other. The marvel of social dualism found in various social orders in the worldwide South, contends Keddie (1980), is a consequence of a forced and endorsed modernization from above and it simply creates - post-customary fragments in a conventional society. Regardless of whether we call it - post-conventional or - modernist, we have to recollect that in the previous 150 years, there has been a progression of ontological and anthropological experiences between the two fragments. We have to remember that ordering these unpredictable experiences into double groupings of - tradition and -modernity would misrepresent the wonder (Jahanbegloo, 2002). Additionally, the two sections of conventional and innovator are diversified and there are different layers inside every one of them that may contain conflicting components and observations (Chehabi, 1990). It has been contended that up until the finish of the nineteenth century, the conventional Islamic culture, in spite of the fact that polylithic in nature joined the Iranian individuals and furnished them with a typical point of view on life (Chehabi, 1990; Keddie, 1980). The beginning of a double society, be that as it may, happened when in mid-nineteenth century more contact with the Western world acquainted another perspective with the general public, explicitly the decision layers (Chehabi, 1990; Keddie, 1980). Over the span of time, every one of these predominant layers has additionally built up their plan and created their particular discourse. So as to comprehend the situation of women inside the unpredictable and dynamic force relations which have been working and molding the texture of the Iranian setting, the following area will concentrate on the development of the two predominant discourses of Islamization and modernization. So as to stay away from the risk of essentialism, I have to underline that my point here is not to solely amplify the job of these two principle classifications, but instead to concentrate on the job and capacity that these primary classes play in the multiplication of gendered identities which are truly, socially and politically built. Remember that women in Iran are significantly inserted in different covering social relations and take part in numerous social jobs that help shape their encounters.

\subsubsection{Islamisation Discourse}

It is imperative to explain toward the start of this segment the term -Islamization should be separated from Islamic. The Iranian culture like numerous other Islamic social orders has consistently been fundamentally overwhelmed by a conventional Islamic culture (Lapidus, 2002). Except for the upper and working classes, most of women followed the conventional Islamic standards, incorporating wearing hejab in the open circle and were restricted to play out the household assignments of a spouse and mother (Sanasarian, 1982; Metz, 1987; Sedghi, 2007). Another political translation of Islam and Shi'ism specifically, notwithstanding, turned into the hypothetical reason for various well known political powers in the 1970's and later for the Islamic Revolution of 1979. The term Islamization depends on a politicized perusing of Islam and indicates a progression of exacting practices in the private and open circles which strengthen the standard of a religious political framework. As it were, it is proposed that the post-progressive Iran is a greater amount of an Islamized society instead of an Islamic one (Mehran, 2002). 
As to position of women, the new politicized Shi'ite philosophy contrasted from the conventional quietist Shi'ite understandings in a manner that as opposed to contradicting women's support in the public arena, it pushed the new elective ideas on women as instrumental political specialists who were guaranteed to be given the option to satisfy their characteristic senses just as take an interest in public activity (Yeganeh, 1993, p. 9). Women's support in monstrous numbers in the road exhibitions of 1978-79 constrained the progressive ministers, who had censured women entitlement to cast a ballot in 1963, to change their position definitely and to embrace women political rights as a strict obligation (Tohidi, 1991). This denoted a significant move in the Ulama's (Islamic researchers) impression of women's job (Kian, 1997, Afkhami, 1995). Nonetheless, an occurrence following the upheaval represents what occurred not far off. Ironically the Iranian Revolution and the establishing of the Islamic Republic of Iran (1979) matched with the United Nations Decade for Women (1975-1985). Close by a fast Islamization process, the state started to force its exacting sexual orientation approaches that can be viewed as man centric as opposed to emancipatory; stubborn on sex contrasts and female family life (Tabari and Yeganeh, 1982; Tohidi, 1991; Moghaddam, 1995, 2003; Paidar, 1995; Sedghi, 2007). As in different upheavals, there has been a - complex, gendered convergence of family, religion, and state (Bush and Mumme, 1994, p. 344) in the progressive and post-progressive procedures and their sequential results. Regardless of the way that women's situation in the family and society, too, as their individual and human rights have been genuinely subverted inside the limits of the religious framework, it is noteworthy to take note of that they have stayed dynamic in social, instructive, financial and work circles (Yeganeh, 1993). As Mehran (2002) contends, it was essentially difficult to segregate the women who participated in an unrest and increased social mindfulness and power them back to their local lack of involvement.

In the course of the most recent four decades, different verbose disciplinary practices have been continually grinding away comprising female subjectivities. It has been proposed by various scholastics that both common and criminal laws target subjecting women's status and fortifying male mastery (Afshar, 1985; Yeganeh, 1993; Afkhami, 1995; Bahramitash, 2003; Kheiltash and Rust, 2009). Subverting women's familial rights, the law unequivocally positions the spouse as - head of family unit, and awards him rights, for example, polygamy, separation, and care of kids. Article 33, for instance, expresses that a women's declaration in all polite and criminal cases is worth a large portion of a man's. As per the Law of Retribution and Punishment, the pay paid to the group of a killed woman is a large portion of that of a killed man (Article 46). It has been contended that such instruments have perpetrated a serious blow on the status of women in the public eye and brought about astonishing State and aggressive behavior at home in the post-progressive period (Yeganeh, 1993). It is critical to take note of how the usage of these laws and guidelines endeavor to irritate women's subordinate situation in the public arena (Bahramitash, 2003; Kheiltash, and Rust, 2009).

\subsubsection{Modernization Discourse}

Disregarding the overwhelming authority discourse in present day Iran and its happy declarations of the triumph of the Islamic qualities, there exists an assortment of discourses that assume their jobs in the digressive rounds of intensity. It is inside this variety of different 
clashing discourses that relations of intensity are being characterized. The urgent nearness of the Islamization discourse addresses all parts of open and private life; be that as it may, it is a long way from a solid discourse. Advancement has likewise brought about bunch of changes and difficulties in contemporary Iran. The principle promoters of the informal pioneer discourse in Iran have been the Iranian scholarly people and scholastics who characterize innovation as far as secularism, logic, pluralism, and common society.

When all is said in done, advancement is a method of thought and life which includes question, decision and uncertainty while permitting conversation, difference, discussion and discernment. As indicated by Jahanbagloo (2002), Modernization in the Middle East, as in the West, includes a Weberian procedure of secularization, especially a supplanting of strict foundations with those of soundness. The pre-present day patrimonial nature of the Iranian culture in the mid-nineteenth century saw indications of endeavors at demising the inborn establishments and recreating Iranian national personality (Behnam, 2002)

In spite of the fact that the experience of innovation in Iran occurred in the mid - nineteenth century, the foundation of the Pahlavi tradition in the mid 1920s denoted the time of an orderly procedure of government-coordinated modernization in Iran. The monarchs' intervention in the social scene took structure in their endeavors at advancing the old common culture and building up present day lawful, instructive and military establishments (Abrahamian, 2008; Moaddel, 1998). There was a superimposed accentuation from above on patriotism as a more restricting power than religion. This sort of interest with the Western thoughts of illumination, be that as it may, prompted a social Westernization which disregarded the political backups and estimations of innovation, for example, popular government, pluralism, and common society (Behnam, 2002).

A significant part of the Pahlavi monarchs'(1925-1979) modernizing ventures included changing the status of women in the customarily male centric Iran. Advancement, comparable to ladies' status, can be characterized concerning ladies' jobs and obligations in a general public. As ahead of schedule as 1932, various Iranian ladies took an interest in the Oriental Feminine Congress in Tehran during which in their endeavor to improve their status, they called for correspondence with men in conjugal, instructive, proficient and political rights (Weber, 2008). Presumably the most sensational sign of women passageway into the open circle, notwithstanding, was the required divulging forced on women in 1936 by Reza Shah (Pappe, 2005; Moaddel, 1998). For the dictator ruler, female liberation was a modernizing signal which likewise furnished him with the intensity of using sex, as indicated by Sedghi (2007), to castrate strict specialists and move man centric force from the space of the ministry to the domain of the state (p.67). To additionally build up authority over the administrative specialists who controlled the outdated framework, he endeavored at discharging the instructive framework from the strict space. Reza Shah's instructive change strategy brought about the foundation of the main current schools just as the principal college for the two women and men, notwithstanding a women school in Tehran (Sedghi, 2007). The secularization of the instructive framework permitted women to enter advanced education foundations as understudies and instructors. In 1936-37, 70 young women were admitted to the Tehran University. The modernization venture was continued by Mohammad Reza, who 
prevailing to seat in 1941. Through a US-drove program of modernization, solid furnished rulers around the globe, for example, Mohammad Reza Shah had to subscribe to certain financial and social changes focusing on the urbanization and industrialization of their social orders (Bahramitash, 2003, p.552). During the 60's, these projects came to fruition in Iran, in type of a progression of changes called the - White Revolution which were likewise arranged for the most part so as to forestall significant social and political difficulties. In spite of the fact that at the core of this supposed progressive bundle was the land change, it additionally incorporated the women's entitlement to cast a ballot (Chaido, 2006). To additionally propel women's situation in the household circle, the state changed the Family Protection Law in 1967 and 1975. Before women were chosen for the Parliament and were named as pastors and judges (Peppe, 2005, Baharamitash, 2003).

By actualizing the top-down measures, for example, required disclosing, women testimonial, major legitimate changes, advancing women training, and opening certain callings to them, the Pahlavi line supported women's dynamic investment in the social circle. This sort of - state women's liberation as Sedghi (2007, p.3) keeps up, prompted women organization developing progressively obvious. Because of the monetary development of training and wellbeing, women especially from the center and high societies had the option to enter the work power. Notwithstanding, the lives of other women particularly from the customary white collar class just as the lower classes and rustic regions did not experience any emotional change (Bahramitash, 2003). The impediment of the changes was because of the nonappearance of a vote based framework and the predominance of man centric standards and qualities. In this manner, the general public kept on sticking to customary perspectives and conduct; where esteems, for example, virginity, humility, modesty, loyalty and acquiescence to men's sexual wants and male predominance in the family stayed as authentic social standards and practices (Sedghi, 1996, p.116). Restricted instructive and expert open doors for women made it hard for most of Iranian women to conquer their subjected status and accomplish liberation.

In spite of all the limiting practices on the situation of women after the topple of the Shah and the appearance of the Islamic Revolution, the discourse of advancement seeing women situation as dynamic individuals in the social, political, financial, social and instructive spaces remained generally solid (Mehran, 2003a). women from both the mainstream working classes and the urban lower classes assumed a functioning job in the Revolution and toppling the Shah by exhibiting in the roads of enormous and little urban communities. Much after the Revolution and regardless of the new system's endeavor to keep women in their conventional job, they continued battling to additionally change the open scene with their quality. A long way from being latent casualties, women bit by bit attempted to move out of the destined man centric social edges. Confining estimates, for example, forced veiling and limiting lawful rights, couldn't shield them from discovering ways round the constraints of the male centric framework (Moghissi, 1999). women have utilized various systems, either from an altogether innovator secularist point of view, or a pioneer Islamist see so as to make a more sex friendly condition in the social, legitimate, instructive and proficient circles. The innovator Islamist sees which is mostly founded on a cutting edge perusing of the Sharia likewise attempts to 
accommodate the contrasts between the strict regulation and common logic targeting encouraging women entrance to the open space. Moghissi (1999) accepts that women accomplishments show the decision framework's trade off under the financial, social and political weights. Endeavors towards innovation, regardless of whether Islamic or secularist, have brought about specific changes, for example, further access to training, better openings for work and a general nearness in all circles of life (Mehran, 2003a). Alavi (2005) reports that, $33 \%$ everything being equal, $60 \%$ of government employees and $80 \%$ of all instructors in Iran are women. It is huge to take note of how the official discourses of Islamization with its inside and out analysis on the Western social 'debauchery" and sexual indiscrimination has been not able to contend with the informal innovator discourse (Moghissi, 1999). The fundamentalist discourse has progressively ruined itself before the number of inhabitants in urban center and lower class women. Extraordinary advances in the methods for correspondence and data has brought about the implantation of parts of innovation and obliged a social structure which bit by bit has been changing the forms of the Iranian culture.

\subsubsection{ELT in Higher Education}

In Iran, English language is acquainted with understudies from the age of twelve (grade 7) as a mandatory subject inside the optional educational system (3-4 hours of the week) where the choices in regards to the reading material determination and tests are directed by the Ministry of Education in a top-down educational program. (Eslami Rasekh and Valizadeh, 2004). There are additionally various private English language organizations everywhere throughout the nation that are self-financing yet heavily influenced by the Government. English is offered in all state and private colleges in Iran as constrained courses of 3 credits General English and English for Academic Purposes (EAP) in which understudies focus on the field-related English writings and phrasing (Talebinezhad and Aliakbari, 2002). English major understudies can be put in three fundamental classes: English Language and Literature, Teaching English as a Foreign Language, and English Translation. In the initial two years, understudies center around the primary language aptitudes, while in the accompanying two years, they are offered courses identified with their particular course of study (Talebinejad and Sadeghi Beniss, 2005).

With respect to the showing approaches, a blend of sentence structure interpretation strategy and sound language specialist utilized for the General English courses. EAP courses, then again, for the most part center around the improvement of the learners' reading expertise. ELT course readings and materials utilized at the advanced education foundations are arranged and affirmed by the Ministry. The way of life of instructing in the English language classes in Iran are commanded by an instructor focused methodology (Talebinezhad and Aliakbari, 2002). Educators of English at college level are to great extent Iranian nationals and there are not very many local speakers of English who are allowed to instruct at Iranian advanced education establishments. English language instructors in Iran can acquire their degrees from different unknown dialect programs offered by Iranian colleges. Ma and $\mathrm{PhD}$ graduates in the fields of TEFL or English Language and Literature are viewed as able to instruct at college level (Talebinezhad and Aliakbari, 2002). 
2.2 Conceptual framework: Poststructuralist Feminism: An Alliance between Foucault and Feminism

Gendered poststructuralist hypothetical structure which is reliable with the hypotheses of Michel Foucault (1972, 1978, 1980, and 1988) from one viewpoint, and Feminist speculations of sexual orientation (Weedon, 1987, 1999; Walkerdine, 1989; McLaren 1993, 2002; Butler, 1993, 1999, 2004), on the other, gave the plan and later the diagnostic translation of the information. I attempted to show how subjectivities are evoked and created through fundamental regularizing and disciplinary discourse established in the force systems (Foucualt, 1978a, 1978b). I likewise appeared so as to look at the female teachers' multiple personalities; I have to apply a gendered hypothesis of subjectivity as the establishment of the information examination (Weedon, 1987, 1999; Butler, 1993, 1999, 2004) since it empowers me to concentrate on the regulative and disciplinary strategies that decide the conceivable outcomes of sex and sexual orientation for the female subjects. Focusing on the TESOL writing relating to the key territories of character development, I will attempt to show the lacking worry with the teachers' subjectivities in TESOL research when all is said in done, and inside Iranian TESOL, specifically.

\subsection{Women Issues and ELT in Iran}

At the very beginning of this examination, I understood there exists an enormous hole of studies on issues of personality in the Iranian ELT writing. This, nonetheless, does not involve that I could not discover examines identified with sexual orientation relations in Iran. There were different explores with respect to the character development of outsider Iranian women from alternate points of view. Shahidian's (1996) examination concerns the sexual orientation relations and personality among banished women, while Kaighobadi and Ahrens, (2007) were worried about the women's activist character improvement of Iranian migrant from a mental viewpoint. Khoei, et al (2008) investigated the significance of sexuality to Muslim Iranian women foreigners in Australia. There additionally exists a majority of studies identified with women issues and sexual orientation governmental issues in Iran, especially from two parts of common women's liberation (Najmabadi, 1991, 1998; Hendessi and Shafii 1995) and Islamic woman's rights (Mir-Hosseini, 1996a, 1996b, 2004). In spite of their disparities in points of view, the two gatherings of women's activists in Iran target improving women status. The mainstream women's activists accept that the Islamic women's liberation is a trade off with male controlled society (Mojab, 1995, p. 25). The Islamic women's activists attempt to separate themselves from the political belief system and the - absolutist and legalistic Islam that centers around women sexual and household obligations (Mir-Hosseini, 2002, p. 37). This new age of women's liberation, as indicated by Mir-Hosseini (2004) speaks to another cognizance, another perspective, a sexual orientation talk that is _feminist' in its goals and requests, yet is _Islamic' in its language and wellsprings of authenticity (p. 3). I additionally went over examination identified with sexual orientation issues inside the Iranian advanced education, when all is said in done. Mehran (2003a, 2003b, 2009) and Alavi Hojjat (1994) focused on the women status inside the advanced education framework in Iran, while Higgins and Shoar-Ghaffari (1991) explored sex-job socialization in Iranian course books. Worried about the issue of disparity in training, Kheiltash and Rust 
(2009) contemplated the portrayals of sex in school course readings and educational programs.

In the ELT research field, nonetheless, a large portion of the examination completed in Iran centers around issues identified with language learning techniques, systems and the related study hall rehearses. I additionally understood that the main part of Iranian ELT research is under the spell of positivism and most of analysts demonstrate an impressive propensity to use quantitative examination system. The current ELT models in Iran are inspected by Talebinezhad and Aliakbari (2002), though, Sarani and Kafipour (2008) focused their work on the language learning procedures. The examinations completed by Izadinia (2009), Matbouli (2009) and Ghahremani-Ghajar and Mirhosseini, (2005) were worried about issues of intensity and basic instructional method, while Aliakbari (2002) for example, assessed the issue of culture inside the ELT program in secondary schools. By and large, the subject of the ELT and character development has been up to this point insufficiently inspected. I could not discover any examination on the topic of female EFL educators' development of identity, either through a poststructuralist or a women's activist point of view. The hole in writing, itself, accordingly, turned into a significant inspiration and made me increasingly resolved to set out on this untrodden street.

\subsection{Poststructuralist Research on Teachers' Identity Formation}

As I continued looking for research that has handled the issue of identity development from a poststructuralist point of view, I went over different examinations that concentrated on various themes identified with educator character, for example, the expert, sociocultural and political setting (Duff and Uchida, 1997; Beijaard et al., 2004), the elements of good issues and qualities (Johnston, 2003; Phan Le Ha and Phan Van Que, 2006). In their audit of studies in regards to language educator character, Varghese et al (2005) bring up three primary viewpoints: conceptualizing way of life as numerous, moving and clashing; the worry with the nearby interrelation of identity with sociocultural and political setting; and the idea of the desultory development of identity. Crafted by Coldron and Smith (1999), Moore, et al (2002) examines the interrelation of the office and social structure in the instructing calling. Underscoring on the logical idea of instructor identity, Coldron and Smith (1999) accept that the character of an educator involves where, inside the expert relevant cluster of potential outcomes (p. 714). Moral issues and inquiries of qualities have likewise been main focus in a portion of the examinations identified with educator identity. Managing the elements of qualities in shows' personality development, Johnston (2003) investigates the ethical part of educator understudy connection, instructor's perspective on herself as an expert and the job of instructors' strict convictions in ELT. In their subjective investigations of the idea of the rambling development of character among Vietnamese instructors of English, Phan Le Ha and Phan Van Que (2006) attempt to investigate the relations between the individual, expert and good identity discourse. Their work is essentially worried about the manners by which Vietnamese Western-prepared instructors arrange their identity concerning their virtues in educating English. The focal point of these investigations is on the difficulties and complex procedures non-local educators of English utilize confronting values conflicting to their own. Focusing on the mind boggling interrelationships among language and culture, Duff and 


\section{Mll Macrothink}

Uchida's (1997) ethnographic examination investigates teachers' sociocultural identity and their showing rehearses in the postsecondary EFL homeroom in Japan. In another investigation on the expert identity of non-local English educators, Anita Dewi (2007) examines the effect of language and culture drenching on the expert character of Indonesian EFL instructors. Tsui (2007) inspects the expert identity of a male EFL Chinese instructor through an account request. Investigating the instructor's battles with various characters, this examination features institutional development, on one hand, and the educator's very own recreation of identity, on the other. Boyd's (2000) study discourses about the procedures of identity development in an alternate gathering of members. He centers around the social adjustment of four Canadian English instructors who worked in Japan, just as their readapatation in coming back to their nation of origin. Golombek and Jordan (2005) additionally apply a poststructuralist framework in their investigation of pre-administration teachers' multiple and clashing characters. They contend that by offering elective discourses, instructor training projects may empower pre-administration educators to envision elective characters. These explores utilized different techniques and apparatuses, for example, ethnography, interviews, journals, perceptions, and contextual investigations in their work on social identity and language instructing Comprises an assortment of various and changing force relations.

\section{Method}

\subsection{Research Questions}

There are sure issues which I accept are vital in understanding the procedures and methods in which the female Iranian ELT instructors make and build up a feeling of self. My first significant concern is identified with this woman's feeling of self and the fundamental subject places that are made viewing her jobs as a woman and as instructors. These subject positions, in any case, are the results of normalizing and administrative discourses that are accessible inside her social and expert setting. By characterizing and deciding the ordinary and characteristic', these administrative discourses target evoking and molding her identity (Foucault, 1978a; Giddens, 1992; Czarniawska-Joerges, 1997). In this manner, the accompanying inquiries will be tended to and recognized from a hypothetical just as an experimental point of view:

1. What establishes the members' ways of life as female ELT educators in Iran?

2. What are the predominant discourses that shape their characters?

Utilizing these directing inquiries and concentrating on the important topics in the meetings with my members, I had the option to take advantage of a priceless wellspring of material for the examination of the Iranian female educators' identity and the predominant digressive practices.

\subsection{Participants}

Before any endeavor to investigate the instruments of intensity in building instructors' 
characters, I attempt to focus on my member's close to home and expert narratives. It is noteworthy to take note of that the social and true to life surface of the member's beneficial encounters can help us in our endeavor to uncover the prevailing discourse that have been continually forming and reshaping her character. In their longitudinal examination on educators, I concur with Flores and Day (2006) on the huge effect of instructors 'individual and expert setting as deciding elements on their identity.

\subsubsection{Participant's Background}

The participant of the study is an English professor who teaches at a University in Tehran. She also used to teach at different English institutions for more 10 years. She is named Afsaneh after this. Afsaneh holds a PHD degree in English language teaching from Tehran University. She is 48 years old and married with a daughter. She was born and raised in one of the small villages in west of Iran. Her native language is Farsi.

Afsaneh told me that her family was very poor and due to this reason she had to work in other people houses to help them with different domestic chores since age 7 . She had a very patriarchy family and his father was a decision maker in her family and she remembers that they were actually afraid of him and they were like strangers to each other because her father believed that girls belong to other family due to the fact that they will get married and leave the home but boys are the ones that you should take a good care of because eventually they are the ones that will inherit everything and will take care of the parents in their old age. Her father was not agree to send Afsaneh to school because he thought that it was a waste of time and it was better for her to work and make money but her brother went to school despite the fact that he did not like it. Fortunately, Afsaneh had an aunt who lived in Tehran and after days of argument Afsaneh was allowed to go to school under one circumstance that she had to work after her school to help with family expenses. Her mother got married with her father when she was 12 and she had her first kid in the age of 14 so it was expected for Afsaneh to get married in the same age. In fact, child marriage was a tradition in her village. She remembers that men specially old ones came there to find themselves young brides; they were willing to pay good money for the bride as well and money was one thing that villagers could not say no to because most of them were very poor. Afsaneh refused to get married to a 65 year old man who was willing to pay good amount of money in exchange of her in marriage. However, her father insisted and threatened her that she would be disowned and she was already too old to stay at home and she would disgrace her family if she refused to get married. Afsaneh was under such a pressure that she had to run and leave the house in order to save herself. Her aunt who used to leave in Tehran offered to help her so she went to Tehran by the money that her aunt sent for her. Her father found out about this and went after her to make her go back and get married but with the help of her aunt she refused to do so and stayed at Tehran but she lost her family from that day and they disowned her and did not want to have anything to do with her anymore. In fact, her father announced her dead when he came to their village. She was at shock for a while but with assistance of her aunt, she managed to continue her life as well as her studies.

She did her best at school and she was top student through high school and university. Since 
English language always symbolizes freedom for her because according what she had seen in the movies and in the news, women could lead a free life in developed countries where English is their native language. Hence, she fell in love with this language and it motivated her to do her best to be as successful as possible in this major. Of course, she started learning English when she was at high school. She went to an English institution to learn the language as well as possible. Then, she realized that she was actually a very good language learner which motivated her even more to pursue this major at university. She actually made it and now she is a successful English professor. Afsaneh got married with her colleague when she was 30 years old and had her child when she was 32 years old.

\subsection{Data Collection}

The information for this subjective examination was gathered through stories. Stories have gotten a lot of consideration over the previous decade and speak to the principle collection of information for examining instructor discourse. As indicated by Barkhuizen, Benson, and Chik (2014), stories are valuable apparatuses in instructor character research since they "catch the nature and significance of encounters that are hard to watch straightforwardly and are best comprehended from the point of view of the individuals who experience it" (p. 8). They additionally permit instructors to view themselves as and their activities as socially and verifiably arranged (Johnson and Golombek, 2002).

So as to acquire teacher's stories, 6 meetings were led with the member. Each meeting kept going an hour. The meetings were led in Farsi language and afterward were converted into English. The deciphered writings were returned to the interviewee to be checked for precision of expected messages and implications.

\subsection{Data Analysis}

The information of instructor's accounts was broke down by utilizing constant comparative strategy (Glaser and Strauss, 1967). In consistent similar technique, the specialist creates topics and ideas by coding and investigating the information simultaneously (Taylor and Bogdan, 1998). The following steps were taken to analyze the interviews. Step 1 included Organizing and preparing the data for analysis by transcribing the interviews sorting and arranging the data into different types according to the different sources of information. Step2 involved the reading through all the data and getting the general sense of it. Step 3 involved starting the coding of the data by organizing the data in brackets or chunks. Step 4 included using codes to generate themes and reporting them. In step 5, the researcher put the themes in narratives. The last step involved interpreting the data based on the personal experience and previous literature (Creswell, 2014).

To guarantee believability of the coding, the information were coded by another autonomous coder and Cohen "es Kappa coefficient was applied to the outcomes which delivered bury coder unwavering quality of .90. What's more, the legitimacy of the discoveries was checked by utilizing participant checking. The participant instructor was approached to peruse the subjects and assess the exactness of the outcomes. This area incorporated an extra meeting with the member. The aftereffects of this meeting were applied in concluding the discoveries. 


\section{Results and Discussion}

The thematic analysis of data revealed that different discourses affect women English language teachers' identity in Iran. Regarding to this matter 7 themes emerged which will be explained thoroughly in the following paragraphs:

\subsection{Not Good Enough}

One theme that emerged through the data was the feeling of not being good enough. This lack of self- confidence that mostly caused this feeling has to do with the very old culture and tradition that made women try to prove themselves in every single task that they are involved in. Despite the fact that Afsaneh has been through a lot since very young age since she had to run from her family, she managed to become a successful professional woman who was at the top of her class all through BA and MA. However, she still thinks that she is not enough and she is putting herself through a lot to be a perfect teacher, wife and mother. Of course we can pin part of this feeling as mentioned in her interview not to let anything ruins her family so she can keep her family together but she also mentioned that her friends are suffering from the same negative feeling which brings up this question why Afsaneh despite all her achievement is feeling like this all the time? She expressed:

" No matter what I do or how much I try and do my best to get better at and better every day at what I do as a teacher, as a mother and wife, still there is voice in my head that tells me I'm not good enough and I need to do more and be better. Some of my friends have the same feeling as well. I think it is epidemic among women or at least among women that I know. For me I guess partly the fact that I lost my family once when I was so young has to do with it so I always try twice as necessary to prove that I am good enough. OF course I know I did the right thing( running away from my family), my mind confirms it but some part of my heart simply miss my family, specially my mother whom I haven't seen for 33 years. Perhaps this hole that I feel in my heart is the reason that I always try to assure my daughter that I love her and no matter what she wants in her life, I will be there for her to support her and help her to achieve all she wants in this world. But I suppose my daughter thinks that I am being over protecting of her by trying too much not to let anything bad ever happens to her. There is the issue of being a best wife too. Despite the fact that I am always super busy with university work and taking care of my daughter, I always try to cook the best meals for my husband and keep the house as clean as it gets and pay attention to my husband's feeling and listen to his complains about his day at work and being patient. Sometimes I get too exhausted with all these overwhelming tasks but I just do not want to lose my family all over again. Maybe, besides love, fear is another fuel to make my engine working and keeps me going forward with my life. It really would not hurt if I felt that I was enough so I would not have to be restless all the time. I don't really know why women always try to satisfy everyone and being nice and kind to everyone. Being a woman is the most difficult task to fulfill. If I was a man; I never had to lose my family in the first place and feel terrible all the time. Life is just so much easier for men in Iran. They are free to be anyone they want and there are always women around as their mother or wife to take care of them and make sure that they get what they want in their life." 


\section{Mll Macrothink}

Journal for the Study of English Linguistics

ISSN 2329-7034

2020, Vol. 8, No. 1

This feeling may have to do with the fact that she is trying to be modest and humble about her achievements as well but there is this deep feeling of frustration and insecurity which engage her in the process of proving herself all the time. Beyer (1999) and Beloff (1992) report women under-estimation of their prosperity and execution. Girls' modesty preparing during the time spent socialization, as Beloff (1992) contends, may be responsible for such sentiments of absence of certainty. Walkerdine (1989) depicts the wonder as the manner by which femininity is perused as a star grouping of signs which mark it off as contradictory to 'legitimate' execution to a mind boggling degree (p. 268). She accepts this sentiment of lackluster showing regardless of women prosperity is the consequence of the verbose creation of womanliness as contradictory to manly judiciousness to such a degree, that femininity is likened with horrible showing, in any event, when the young woman or woman is being referred to be performing admirably (p. 268).

\subsection{No Ambition}

Another theme that came up while I was analyzing the data was the lack of ambition. Afsaneh was not willing to take her chances for any administrative positions which raised the question why Afsaneh despite the good professional record does not want to have anything to do with these sorts of positions. Afsaneh mentioned:

"Despite the fact that I have been teaching English for more than 15 years and I am more than capable for managerial and administrative positions, deep down I think that I do not really deserve it or no matter how much I try to get it, they will still get it to a man whom they believe are born to lead. I don't know where this feeling come from but I know for sure that literally no women in Iran hold the administrative position such as dean of the university or a judge of the court of law. In fact, I believe that being a judge is forbidden for women in Iran. Therefore, whenever I think about matters like this, I just get disappointed already and something tells me if someday, I even manage to get this done, I am sure that men out there will be offended and make my life a living hell simply because I am a women and women belong at home and their main job is cleaning the house. I don't know these sorts of thought just paralyze me because I am already fighting so many battles in my life just for being a woman so adding another just seems unnecessary."

Measurements in Iran, as in numerous different settings, show that women are underrepresented in the regulatory situations inside advanced education (Mehran, 2003). The 'biased based impediment' impact mirrors the obvious and imperceptible sexual orientation hindrances for women to ascend high in the chain of command of occupations, in spite of their instructive and expert capabilities (Cotter, et al, 2001). Court (1997) attests that, women are built as normally 'fit (as a result of their science and youngster bearing abilities) to the essential jobs of moms and spouses (p. 19); in this way, their household obligations become their primary goal. As indicated by Court (2007), such confining and debilitating desultory developments and practices can shape women's feeling of self. This perception is huge since it might show how the discourse of contrast focuses on sexual orientation polarities that are hierarchic, and , thus, prompts segregation, mistreatment and underestimation of women in the entirety of their own and social parts of life (Weatherall, 2002, Stone, 2004, Render, 
2006). These jobs are bogus ideas, as Render (2006) depicts, that work as an instrument of control propagating a pattern of subjection, supporting and characterizing as women's jobs in the social structure (p.108).

\subsection{Manly Femininity}

Another important theme that emerged while I was going through Afsaneh interview was masculine femininity. It was really interesting because despite the fact that she asserted earlier that she constantly feels that she is not enough and she feels insecure both as a teacher and a woman, she was ready to show dominance, control and self-confidence when it was necessary especially at her work. This part of her identity showed itself the most when she was at work. Afsaneh asserted:

"Teaching all male student class always has been the whole different challenge for me because male students find it really difficult to be managed and controlled by a woman. In Iran, Men are raised in a way that most of them believe that they are the superior gender and they are the only ones that must be in control and it is simply humiliating for their huge ego to be in a class where women are in the position of the control. Hence, teaching in an allmale class is like the whole new battle to fight just to prove that class is your territory and despite the fact that you are a woman, you are very capable of teaching a class even better than a male teacher. Practically, a lot of times in a class especially in beginning sessions are spent to prove this point; otherwise students will not follow the class and will try to make a joke out of it. So for me it is part of a main ritual to settle this matter first, and then start teaching in the class. Of course you might think this story will end when you succeed to take the control of the class but it is only the tip of the iceberg. Because male students will start call you a man and relate you to masculine adjectives due to the fact that you can control your class and be strong. Male students simply relate being strong with masculinity and they cannot accept that you can be a woman and strong simultaneously. There is no winning or feeling of satisfaction in teaching all male classes. It is more like a vicious circle where you have to prove that you are worthy of their precious time."

This part of the identity makes more sense when being assertive, being in control and attributes like this that show strength is associated with male value in a society. Femininity and masculinity are socially constructed and they can be asserted by both men and women. From a poststructuralist women's activist point of view, sex is performative and showed through our social exhibitions (Butler, 1997, Weitz, 2003). By building themselves as severe, decided, prevailing and blunt creatures, the female scholastics perform manliness (Ashmore, DelBoca, and Wohlers, 1986) and accordingly, the male as standard lacks are strengthened (Acker, 1994, p. 140). Denying the women inside them and indicating a manly picture of themselves, regardless of whether it is constrained to the time they are in the every male class or managing the male collaborators, is a path for them to contend and make due in the male's universe of the scholarly community, where "the professor's Chair seems uniquely shaped for the male body"(Walker, 1998, p. 337). 


\subsection{The Good Wife}

Another theme that emerged from the participants' narratives regarding the feelings and behavior of women was the requirement of being a good wife. It seems that in Iran the identity of the woman cannot be complete until she gets married and marriage in women's mind is a symbol of security where their main duty is comforting their husband's needs. Despite the trauma that Afsaneh suffered when she was only 12 years old, she still thinks that marriage would bring her security and comfort. She even put her husbands' needs and demands at the top of her list and to do so she started her career as a part of university teacher just to have enough time to take a good care of her husband. The feeling of disappointment and frustration could be observed regarding marriage throughout her interview. As she mentioned:

"Putting various sorts of challenges aside, challenge of being a good wife is the whole new story. You know at the beginning years of my career as a university teacher; I decided to work only part time just to be able to satisfy my demanding husband's needs. Despite the fact that he is a university teacher too, he thinks that being a good wife is even more important for me than being a good mother. Sometimes I swear to god than I feel he gets jealous when I am busy taking care of the papers or preparing myself for a class or maybe it is hard to believe that he even gets jealous when I spend time with my daughter. He is too demanding. I taught getting married with the scholar will make my life easier but it only made it more difficult and sometimes frustrating. To tell you the truth, after running away from home when I was 12 years old because my father wanted me to marry a 65 year old man, I decided I was never going to get married ever in my life. But when I was 30 and after the death of my dear aunt who was like a savior in my entire life, I felt really lonely and I really wanted to have a family of my own and this time keep them together at any price and never let go of them. Besides, I wanted to feel secure and complete and at the time it sounded that marriage could provide me with all these blessings. So, when my husband who is from a very different background with parents who are doctors and always supportive of him proposed, I decided to go along with it. I was scared but I imagined he might be different from other egoistic man in my life but it turned out that he was not that different. Of course he is kind and responsible but at the bottom of his heart like any other man in Iran, he believes that the woman's main job is staying at home and taking care of the home and kids. So marriage in Iran can be really disappointing and I don't think that there is any winning in it for women."

Tremayne's (2006) investigation of early marriage in Iran shows that -marriage itself stays essential to the social personality everything being equal, paying little mind to their accomplishments in different circles of life (p.65). To the members in Tremayne's investigation who are women from an unassuming community in Iran, "marriage remained ultimately the prime value" (p.82). These women lacked literacy or had high school diploma. As Aisenberg and Harrington (1988) contend, "the focal precept of the marriage plot is that a women's legitimate objective is marriage, or, all the more by and large, her essential circle is private and household (p.6)."the identity of a married woman is clear at all times, unlike that of an unmarried woman, who is viewed as a failure and remains in limbo in her social interactions" (p.84). Presently women need to work both as supporter and guardian inside the 
residential circle, just as the dynamic member in the working environment (Friedman, Ellen, and Jennifer Marshall, 2004). Tamboukou (2000) alludes to this swaying between the two universes of the family life and open life, the unpaid and paid work, as the Catch 22 of being a female. As was clear in Afsaneh's case, no matter how successful a woman is in her career and how accomplished she is, she has to put her husband's needs first if she wants her marriage to work. Regardless of whether these women, have had the option to make some type of equalization in their private/open lives or not, whether they are hitched to getting accomplices or not, whether they are cheerful or on edge and disturbed, we can see a "self-selected subjection to the traditional norms of marriage plot" (Aisenberg and Harrington, 1988) that constrains them to subordinate their own needs, wants and inclinations to those of their husband's.

\subsection{Motherhood}

Motherhood was another theme that came out through the data and it seems that motherhood is considered as a holy and sacred mission for women and the only thing that makes marriage a good event. It sounds that women accept the sacrifices and self -denial that involves with becoming a mother and they are kind of proud of it and they are willing to dedicate all their time and energy just to get it right. Just like what Afsaneh is doing as a mother, sacrificing a lot just to protect her daughter and she does not mind it as she put it. The experience of proliferation and parenthood is utilized by progressive systems of capacity to put the duty on moms for being the wellspring of extreme help and penance. Inside the Iranian social setting, "motherhood has been reemphasized as women's most important role, and any work outside the home is clearly expected to be secondary in the lives of women"(Higgins and Shoar-Ghaffari, 1991, p.213). Through accounts of commendable moms portrayed as models of love and benevolence, the idea is generally spread for women to meet the perfect picture. As a model of female sex job, a mother discovers hugeness in keeping up solid family bonds and friendly connections ( refered to by Mehran, 2003, p. 273). Afsaneh expressed her idea of motherhood like this:

"When I was younger, I am talking about days right after I ran away from my family, I really didn't like to have kids or get married any way. Mostly because some part of me was afraid that what if my child would be a girl. Then, she would have to suffer just like me. I was preoccupied with this idea that if I get born to a girl, how I am going to protect her. What if I fail as a mother and let her get hurt by all those horrible obstacles that exist in a woman's life especially in a country like Iran where being a woman is like a sin. My mother always told me stories about how disappointed my father was when he heard that I was born since I was a girl. In fact, these sorts of stories were pretty familiar to every girl in our village. My father never called me his daughter. He always used to call me his son. I mean it literally. Of course it was not just a habit of my father, every man in the village who had a daughter used to call his daughter as a son. At some point all of us got used to it and did not really notice it after a while. After I started to live with my aunt who used to call me her dear daughter, I just realized how sweat it can be to be called properly. All these thought made me promise myself never bring an innocent soul in the world and make her to experience hell, only because I wanted to be a mother. Despite all these thoughts, I got married in age of 30 which is 
considered a late age to get married in Iran only because I felt so lonely and empty after loss of my aunt, the only soul that ever cared about me in this world. Two years after my marriage I got born to my precious beautiful daughter and even as I was delivering her and I was in so much pain, I started to think that my daughter also have to go through this pain at some point in her life and I hated myself for that in that moment. When I saw my daughter for the first time, I promised myself that I would never let anything bad happen to her. Now, she is a teenager and despite the fact that she is my only child, I decided to send her abroad when she wants to attend college or university. I want to provide her with all the best opportunities in the world and let her to be a free woman and enjoy being a woman when she got older. Being a mother involves a lot of sacrifices and self- denial but I think these are the attributes that make motherhood so sacred and holy. I believe that becoming a mother is the only thing that makes it worthwhile for women to get married. As a mother I always feel that I need to dedicate everything that I have including love, attention, time and money to my daughter to make her feel secure. Since the day she came to the world, she has been my priority and I don't really mind it. Of course, my husband gets jealous sometimes for all the attention that I give to my daughter. But I can't help it anyway."

All these aspects of femininity are accepted by women and they indicate no sign of rejection which normalize the whole thing. It is the indicator of a fact that all the restriction regarding the motherhood has been normalized and internalized through the years of practice in patriarchal society. As indicated by McLaren(1993), femininity may appear to be willful, yet this thinks little of the intensity of disguise (p.156). Socially worthy sex codes and sex conducts are the results of male centric discourse that will in general control the connections and associations among people by ingraining a façade of _truth' and normal'. When comprised as an object of a specific sort, people can be scattered into disciplinary spaces inside the - grid of social consistency (Scheurich, 1997, p. 98).

\subsection{Hejab}

Another theme that is worth going through is the concept of Hejab. Hejab is considered as a regulation and law and in this study, I am not going through its history or religious roots here. Throughout the interview Afsaneh showed a negative attitude towards wearing Hejab and she found it a tool which men use to restrict and regulate women. Hejab may have different definitions but in this study according to what Afsaneh described it includes wearing loose long outfit that covers the body and a veil or scarf that should cover the hair. This sort of male centric discourse that partners sin with women can be identified in numerous philosophies and societies around the globe (Moaddel, 1998). In any case, the Islamist discourse's distraction with threat intrinsic in female nature prompts featuring and bringing her body under the sexist look and observation (McLaren, 2002, p.155). This is the manner by which as per Scheurich (1997), a gathering is seen or known as an issue (p. 107). Afsaneh expressed her idea about Hejab like this:

"I started wearing Hejab when I was only 7 years old. In fact, my family made me to wear it and it was an unspoken tradition in our village where every girl did it from that age and no question was asked. The only thing that we knew was that not wearing Hejab was a very 
horrible sin and if we didn't wear it we were going straight to hell. The thought of not wearing it was so scary that I wore it even when I went to sleep. Now it's just a pain in a neck. I hate it with my whole being but it is the law, the most ridiculous one, of course. There are actually Special Forces in streets whose main job is controlling women's way of dressing which is both preposterous and scary. All the women at work look the same, it may sound ridiculous but recognizing female students from each other is way more difficult that male one because female students are all wearing Hejab which usually consist of black uniform and scarf which makes it depressing as well. Because in this country woman even don't have a say in what they want to wear and if they god forbid choose to act against the government's will, they will be punished severely both publicly and in the court of law. After all these years, I just can't fathom the idea and get used to it. It is the same story with my daughter too. I remember the day that she was legally old enough to wear Hejab and she kept asking me why she had to wear it; I just could not come up with an answer that would convince her. Because there is no sense in it and it is just another reason for men in this country to control women and prove that they are the ones with power. I hate the whole thing entirely. The interesting part is that they (government, men) keep telling women that Hejab is a blessing for women because it keeps them safe and secure from the eyes of the men and it helps to avoid chaos in a society because women are naturally the source of distraction for men. That's just a joke, right?"

Digressively building women as risky and compromising sexual animals, a perplexing trap of intensity relations endeavors at desexualizing the female body by covering it since the female body is just protected when it is secured. Simultaneously they impart certain sex suitable conduct which incorporates temperances, for example, virginal blamelessness, asexuality and keeping a legitimate good ways from men. In this manner, the female body that means out of the protected restriction of home should be isolated and apportioned from the male by physical and mental limits made by ideological discourse. The disciplinary act of hejab is practiced legitimately on the female body by the man centric force relations since "sexual orientation subjection is the incognito plan behind the development of the ladylike body (Mc Laren, 2002, p.156).

\subsection{Good teacher}

Another theme that emerged was regarding the professional identity of the teacher. The participant of the study believes that a good teacher is born for this job and she needs to know everything there is to know about the subject matter and she must be in control of everything in the class. Afsaneh told her idea about a good teacher characteristic like this:

"I always feel the need to learn as much as possible because no matter in what classes I am, my students expect me to have all the answers to their questions. As soon as they realize that I hesitate and maybe do not know the answer to the question, they will question your authority and I will lose the control of the class. So I always try to work on my different aspects of the knowledge including my linguistic knowledge, the cultural aspect of the language and my pedagogical knowledge. Of course, I think being a good teacher is an innate phenomenon and good teachers cannot be made at universities. Despite this belief that I hold 
about the innateness of the good teacher, I always try to keep myself up to date.”

In his book, The great instructor: Dominant Discourses in Teaching and Teacher Education, Moore (2004), recognizes three discourse in such manner: 1) great educator, being made through training and preparing; 2) great educator being brought into the world with certain intrinsic characteristics; and 3) the 'proficient realism' which is viewed as a center way. Notwithstanding the greater part of distributions and examination on educator adequacy and instructor reflectivity, Moore (2004) reports a predominant conceptualization with respect to great instructors that "(p.4): fruitful instructors are seen not as having been made (not, at any rate, through procedures of educator preparing and training)., however as basically having the secret sauce the ability to order excitement, regard and even love through the sheer power of their homeroom nearness (pp. 4-5). Afsaneh firmly believed that teaching is an innate attribute and another interesting belief that she hold was the teacher needs to know everything and be in control in the class. In another word some portion of being a 'proficient' to the participant as should be obvious through the information, depends on perceiving herself as a specialist in the field who are in control of 'information.' In his conversation of "professionalization", Rose (1998), clarifies how the "guarantee to have recondite information and specialized capacities not accessible to other people (p. 84) adds to making a feeling of self and prompts exercise of intensity. In her work, The Classroom as an Arena of Teachers' Work, Freund (2009), alludes to the well-known depiction of instructor as the chivalrous picture of a fit and tough person who can deal with her group solidly. Building up request in study hall is by all accounts a basic job a large portion of the members attempt to accept.

\section{Conclusion}

These heterogeneous, conflicting and fleeting characters are the aftereffect of the perplexing interchange of sexual orientation and expert discourse inside the setting of Iranian TESOL. As to sexual orientation identities, the main finding is that regardless of the female educator's attention to the sex disparity and segregation inserted inside the male centric culture, she clung to the parallel sex thoughts and social generalizations framed by ruling sex discourses that have crawled into her cognizance all through ages and are grinding away in generally inconspicuous and imperceptible manners. The major normalizing sexual orientation talks identified with womanliness work through an inconspicuous system of discourses including: 1) the discourse of not being sufficient and absence of desire, 2) the discourse of the great spouse, and 3) the discourse of Motherhood. The discourse of not being sufficient shapes the participant's sentiments of instructive and expert insufficiency such that she feels compelled to continually make a decent attempt in demonstrating to others just as herself that she is 'equivalent to men.' The discourse of absence of aspiration additionally creates the subject situation of the unambitious female instructor, who does not have any motivating forces for advancement to higher authoritative occupations. Regardless of the sentiments of insufficiency and absence of certainty, the female instructor performed manliness, repudiating the ladylike inside her by indicating a severe, prevailing and blunt self, at the end of the day, 
_a manly woman so as to contend and make due in a male scholastic world. The Catch 22 of being a female in her wavering between the two universes of the family life and open life is brought about by the two discourses of being a good wife and motherhood eventually prompts a self-chose giving up of her own needs and wants for being steady, mindful, and obliging in her local jobs. Organizing the local jobs shows how these discourses make a generalization trap in an unpretentious and improved manner so guiltlessly that it appears to be an immortal and well known fact for women, while prompting their underestimation in all parts of individual and public activity.

Another discourse that has been completely examined is the talk of Hejab which depends on the dread of the sensual bodies. This sort of gendered portion of spaces inside the Iranian instructive foundations is purified for the sake of religion, or society's security, and endeavors at putting the bodies inside the arranged and controlled openings. The outcome is a feeling of detachment and distance that prompts a sentiment of absence of having a place with the work environment. The other talk that shape female educator's characters is identified with instructing calling. The primary discovering important is that the member thought instructing is a greater amount of a craftsmanship that can barely be scholarly through instructor training programs, in spite of the fact that she esteemed both training and experience. In addition, basic the educator's expert thoughts, originations and inclinations were a specific discourse that I allude to as the discourse of good teacher. The most prevailing subject positions identified with great educator accessible to the female English instructor that formed her recognitions and activities included: educator as the master knower who is in charge of everything in class.

The expert knower endeavors to gain the necessary information and attempts to transmit her gathered information to her understudies. Inside this digressive field, instructors are specialists of control, request and order, and understudies are subject to them as the wellspring of information. Taking everything into account, the discoveries give a brief look to the way that the Iranian female educators 'encounters in reproducing an expert identity at Iranian colleges are the consequence of an interaction of sexual orientation and expert discourse. In this evaluative rundown of the discoveries of the examination, we perceive how these women experience testing limitations and logical inconsistencies that include their status as female English instructors inside the Iranian foundation.

\section{Acknowledgement}

I would like to express my gratitude to the participant of the study who trusted me with her life stories which made this work possible.

\section{References}

Abrahamian, E. (2008). History of modern Iran. Cambridge: Cambridge University Press. https://doi.org/10.1017/CBO9780511984402 
Acker, S. (1994). Gendered education. Buckingham: Open University Press.

Afkhami, M. (1995). Faith and freedom: Women's human rights in the Muslim world. Syracuse University Press.

Afshar, H. (1985). Women, state and ideology in Iran, Third World Quarterly, 7(2), 256-78. https://doi.org/10.1080/01436598508419838

Aisenberg, N., \& Harrington, M. (1988). Women of academe: Outsiders in the sacred grove. Amherst, MA: University of Massachusetts Press.

Alavi, N. (2005). We are Iran. London: Portobello.

Alavi Hojjat, T. (1994). Women in higher education in Iran. In S. Stiver Lie, L. Malik \& D. Harris (Eds.), The gender gap in higher education, (pp. 20-33). London: Kogan Page. https://doi.org/ 10.1086/378248

Alldred, P., \& Gillies,V. (2002). Eliciting research accounts: Reproducing modern subjects? In M. Mauthner, M. Birch, J. Jessop \& T. Miller (Eds.), Ethics in qualitative research (pp. 146-63). London: Sage. https://doi.org/ 10.4135/9781473913912.n10

Aliakbari, M. (2002). Culture in ELT programs: An evaluation of the issue of culture in the Iranian ELT program in high school level. Unpublished doctorial dissertation. The University of Isfahan.

Ashmore, R. D., Del Boca, F. K., \& Wohlers, A. J. (1986). Gender stereotypes. In R.D. Ashmore \& F. K. Del Boca (Eds.), The social psychology of male-female relations. Orlando, FL: Academic Press. https://doi.org/10.2466/pms.2000.90.3c.1283

Bahramitash, R. (2003). Islamic fundamentalism and women's economic role: The case of Iran. International Journal of Politics, Culture, and Society, 16(4), 551-568. https://doi.org/10.1023/A:1023043308813

Barkhuizen, G., Benson, P., \& Chik, A. (2014). Narrative inquiry in language teaching and learning research. New York: Routledge/Taylor \& Francis. https://doi.org/10.4324/9780203124994

Behnam, J. (2002). Iranian society: Modernity and globalization In R. Jahanbegloo (Ed.), Iran: Between Tradition and Modernity (pp. 3-14). Lexington Books.

Beijaard, D., Meijer, P. C., \& Verloop, N. (2004). Reconsidering research on teachers' professional identity. Teaching and Teacher Education, 20, 107-128. https://doi.org/10.1016/j.tate.2003.07.001

Beloff, H. (1992). Mother, father and me: Our IQ. The Psychologist, 5, 309-311.

Beyer, S. (1999). Gender differences in the accuracy of self-evaluation of performance. Journal of Personality and Social Psychology, 59, 960-970. https://doi.org/10.1037/0022-3514.59.5.960

Boyd, D. (2000). Cultural adaptation and identity formation: The transcutural journey and 
identity reformation of four Canandian teachers returning from a sojourn to Japan. Doctoral dissertation. York University, North York, Ontario.

Bush, D. M., \& Mumme, S. P. (1994). Gender and the Mexican revolution: The intersection of family, state and church, In M. A. Tétreault (Ed.), Women and revolution in Africa, Asia, and the new world (pp. 343-365). Columbia, SC: University of South Caroline Press.

Butler, J. P. (1993). Bodies that matter: On the discursive limits of sex. London: Routledge.

Butler, J. (1999). Gender trouble. New York: Routledge.

Butler, J. (2004). Undoing gender. New York: Routledge. Butler, J. (2005). Giving an account of oneself. New York, Fordham. University Press.

Butler, J. (1997). Sovereign Performatives in the Contemporary Scene of Utterance. Critical Inquiry, 23(2), 350-377.

Chaido, A. (2006). Changing role of women in Iran. Kansas: University of Kansas.

Chehabi , H. E. (1990). Iranian politics and religious modernism: The liberation movement of Iran under the Shah and Khomeini. London: I.B.Tauris. https://doi.org/10.1080/10669929308720041

Coldron, J., \& Smith, R. (1999). Active location in teachers ${ }^{*}$ construction of their professional identities. Journal of Curriculum Studies, 31, 711-726. https://doi.org/10.1080/002202799182954

Cotter, D. J., Hermsen, S. Ovadia \& R. Vanneman. (2001). Social forces: The glass ceiling effect. Chapel Hill, NC: University of North Carolina Press. https://doi.org/10.1353/sof.2001.0091

Creswell, J. W. (2014). Research Design: Qualitative, Quantitative, and Mixed Methods Approaches. Los Angeles: Sage Publication.

Court, M. (1997). Who does what at your place? Women educational leaders' experiences of gender-segregated work. Women in Management Review, 12(1), 17-26.

Court, M. (2007). Changing and/or reinscribing gendered discourses of team leadership in education? Gender and Education, 19(5), 607-626. https://doi.org/10.1080/09540250701535642

Czarniawska-Joerges, B. (1997). Narrating the organization: Dramas of institutional identity. Chicago: University of Chicago Press.

Dewi. A. (2007). Asian shifts in NNESTs' professional identity: An impact of language and culture immersion. EFL Journal, 9(4). http://www.asian-efl-journal.com/Dec_2007_ad.php

Duff, P., \& Uchida, U. (1997). The negotiation of teachers' socio-cultural identities and practices in postsecondary EFL classrooms. TESOL Quarterly, 31(3), 451-486. https://doi.org/10.2307/3587834 


\section{Ml Macrothink}

Journal for the Study of English Linguistics

ISSN 2329-7034

2020, Vol. 8, No. 1

Eslami-Rasekh, Z., \& Valizadeh, K. (2004). Classroom Activities Viewed from Different

Perspectives: Learners' Voice vs. Teachers' Voice. TESL EJ, 8, 1-13. http://tesl-ej.org/ej31/a2.html

Foucault, M. (1972). The Archaeology of Knowledge, trans. A. M. Sheridan Smith. New York: Pantheon.

Foucault, M. (1978a). Discipline and punish: The birth of the prison, trans. Alan Sheridan. New York: Pantheon.

Foucault, M. (1978b). The history of sexuality: An introduction. trans. R. Hurley. Harmondsworth: Penguin.

Foucault, M. (1980). (C. Gordon Ed,) Power/knowledge: Selected interviews and other Writings 1972-1977. New York: Pantheon Books.

Foucault, M. (1988a). Truth, power, self: An interview with Michel Foucault. In L. H. Martin, H. Gutman, \& P. H. Hutton (Eds.), Technologies of the self (pp. 9-15). Amherst: The University of Massachusetts Press.

Foucault, M. (1988b). The ethic of care for the self as a practice of freedom. In J. Bernhauer \& D. Rasmussen (Eds.), The Final Foucault (pp. 1-20). Cambridge: Mass.: MIT Press.

Flores, M. A., \& Day, C. (2006). Contexts which shape and reshape new teachers' identities: A multi-perspective study. Teaching and Teacher Education, 22(2), 219-232. https://doi.org/10.1016/j.tate.2005.09.002

Freund, M. (2009). The classroom as an arena of teachers' work In L. J. Saha \& A. G. Dworkin (Eds.). International handbook of research on teachers and teaching (pp. 305-318). Part 5, Springer

Friedman, E., \& Marshall, J. (2004). Issues of gender. New York: Pearson Education.

Ghahremani-Ghajar, S., \& Mirhosseini, S. A. (2005). English class or speaking about everything class? Dialogue journal writing as a critical EFL literacy practice in an Iranian high school. Language, Culture and Curriculum, 18(3), 286-299. https://doi.org/10.1080/07908310508668748

Giddens, A. (1992). The Transformation of Intimacy. Stanford, CA: Stanford University Press.

Glaser, B. G., \& Strauss, A. L. (1967). The discovery of grounded theory: Strategies for qualitative Research. Hawthorne, NY: Aldine.

Golombek, P., \& Jordan, S. R. (2005). Becoming "black lambs" not "parrots": A poststructuralist orientation to intelligibility and identity. TESOL Quarterly, 39(3), 513-534.

Hendessi, M., \& Shafii, R. (1995). Women and the politics of fundamentalism in Iran. WAF journal, 6, 12-15.

Higgins, P. J., \& Shoar-Ghaffari, P. (1991). Sex-role socialization in Iranian textbooks NWSA 
Journal, 3(2), 213-232.

Higgins, P. J., \& Shoar-Ghaffari P. (1994). Women's education in the Islamic Republic of Iran.In M. Afkhami \& E. Friedl (Eds.), The Eve of the storm (pp. 42-43). I.B. Tauris.

Izadinia, M. (2009). Critical pedagogy: An introduction in power in the EFL classroom: In Phyllis Wachob, (Ed), Critical pedagogy in the Middle East (pp. 7-16). Cambridge Scholars.

Jahanbegloo, R. (2002). Iran: Between tradition and modernity. Lexington Books.

Johnson, K. E., \& Golombek, P.R. (Eds.). (2002). Narrative inquiry as professional development. New York: Cambridge University Press. https://doi.org/10.15446/profile.v19n2.65692

Johnston, B. (2003). Values in English language teaching. Mahwah, NJ: Lawrence Erlbaum Associates. Johnston, B. (2007). Decisions, decisions: The moral complexities of ESL teaching. Keynote address given at the Minne TESOL Annual Convention, Minneapolis, MN, November.

Kaighobadi, F., \& Ahrens, C. , 2007-03-08 "Feminist Identity Development of Iranian Immigrant Women and Its Relationship with their Psychological Well-Being" Paper presented at the annual meeting of The Association For Women in Psychology, Golden Gateway Holiday Inn, San Francisco,

Keddie, N. R. (1980). Iran, religion, politics and society: Collected essays. Routledge.

Kheiltash, O., \& Rust, V. D. (2009). Inequalities in Iranian education: Representations of gender, socioeconomic status, ethnic diversity, and religious diversity in school textbooks and curricula in inequality in education, CERC Studies in Comparative Education, 24, Springer, Netherlands

Khoei, E. M., Whelan, A., \& Cohen, J. (2008). Sharing beliefs: What sexuality means to Muslim Iranian women living in Australia. Culture, Health \& Sexuality, 10(3), 237-248. https://doi.org/10.1080/13691050701740039

Kian, A. (1997). Women and politics in post- Islamist Iran: The gender conscious drive to change. British Journal of Middle Eastern Studies, 24(1), 75-96. https://doi.org/10.1080/13530199708705639

Lapidus, I. M. (2002). A history of Islamic societies. Cambridge: Cambridge University Press.

Matbouli, H. F. (2009). Analysis of EFL students' attitudes towards learner autonomy in power in the EFL classroom, In P. Wachob (Ed.), Critical Pedagogy in the Middle East (pp. 75-96). Cambridge Scholars.

McLaren, M. (1993). Possibilities for a non-dominated female subjectivity. Hypatia, 8(1). 153-158. McLaren, M. (1999). Two feminist views on the self, identity and collective action. Hypatia, 14(1), 120-125. 
McLaren, M. (2002). Feminism, Foucault, and embodied subjectivity. Albany: State University of New York Press.

Mehran, G. (2002). The presentation of self and other in the post revolutionary Iranian school textbooks, In N. Keddie \& R. Matthee (Eds.), Iran and the surrounding world: Interactions in Culture and Cultural politics (pp. 232-253). Seattle: University of Washington Press.

Mehran, G. (2003a). The Paradox of tradition and modernity in female education in the Islamic Republic of Iran . Comparative Education Review, 47(3), 269-286.

Mehran, G. (2003b). Gender and education in Iran. Education for All Global Monitoring Report 2003/4. Gender and Education for All: The Leap to Equality.

Mehran, G. (2009). Doing and undoing gender: female higher education in the Islamic Republic of Iran. International Review of Education, 55, 541-559. https://doi.org/10.1007/s11159-009-9145-0

Metz, H. C. (1987). Iran: A country study. Washington: GPO for the Library of Congress.

Mir-Hossein, Z. (1996a). Stretching the limits: A feminist reading of the Sharia in post-Khomeini Iran. In M. Yamani (Ed.), Feminism and Islam: Legal and literary perspectives (pp. 285-319). Reading: Garnet Publishing.

Mir-Hosseini, Z. (1996b). Women and politics in post-Khomeini Iran: Divorce, veiling, and emerging feminist voices, In H. Afshar (Ed.), Women and Politics in the Third World (pp. 142-169). London and New York: Routledge.

Mir-Hosseini, Z. (1999). Islam and gender: The religious debate in contemporary Iran. Princeton University Press.

Mir-Hosseini, Z. (2002). The conservative-reformist conflict over women's rights in Iran. International Journal of Politics, Culture and Society 16 (1). https://doi.org/10.1023/A:1016530427616

Mir-Hosseini, Z. (2004). The quest for gender justice: Emerging feminist voices in Islam. Isla, 21(36).

Moaddel, M. (1998). Religion and women: Islamic modernism versus fundamentalism. Journal for the Scientific Study of Religion, 37(1), 108-130. https://doi.org/ 10.2307/1388032

Moghaddam, V. (1995). Gender and Revolutionary Transformation: Iran 1979 and East Central Europe 1989, Gender and Society, 9(3) 328-358.

Moghaddam, V. (2003). Modernizing women: Gender and social change in the Middle East, Boulder, CO: Lynne Rienner.

Moghissi, H. (1999). Feminism and Islamic fundamentalism: The Limits of postmodern analysis. London: Zed Books.

Mojab, S. (1995). Islamic feminism: Alternative or contradiction. Fire-weed, 47, 18-25. 


\section{Macrothink

Moore, A., Edwards, G., Halpin, D., \& George, R. (2002). Compliance, resistance and pragmatism: The (re)construction of schoolteacher identities in a period of intensive educational reform. British Educational Research Journal, 28, 551-565. http://dx.doi.org/10.1080/0141192022000005823

Moore, A. (2004). The good teacher: dominant discourses in teaching and teacher education. Routledge

Najmabadi, A. (1991). Hazards of modernity and morality: Women, state and ideology in contemporary Iran. In D. Kandiyoti (Ed.), Women, Islam and the State (pp. 48-76). Temple University Press.

Najmabadi, A. (1998). Feminism in an Islamic Republic: Years of hardship, years of growth. In Y. Y. Haddad, \& J. L. Esposito (Eds.), Women, gender, and social change in the Muslim world (pp. 59-84). New York: Oxford University Press.

Paidar, P. (1995). Women and the political process in twentieth-century Iran. Cambridge University Press. https://doi.org/10.1086/ahr/102.1.148

Pappé, I. (2005). The Modern Middle East. Routledge.

Phan L. H., \& Phan V. Q. (2006). Vietnamese educational morality and the discursive construction of English language teacher identity, Journal of Multicultural Discourses, 1, 136-151. https://doi.org/10.2167/md038.0

Rose, N. (1998). Inventing ourselves psychology, Power, and personhood. London: Cambridge University Press. https://doi.org/10.1017/CBO9780511752179

Render, M. (2006). Misogyny, androgyny, and sexual discrimination in a gender-deconstructed, Harvard Journal of Law \& Gender, 20, 99-150.

Sarani, A., \& Kafipour, R. (2008). The study of language learning strategies use by Turkish and Kurdish EFL university students. Language Forum, 34(2), 173-188.

Sanasarian, E. (1982). The Women's rights movement in Iran: Mutiny, appeasement, and repression from 1900 to Khomeini. Praeger. https://doi.org/10.2307/1961899

Scheurich, J. (1997). Research method in the postmodern. London: Falmer Press.

Sedghi, H. (1996). Women, the state and development: Appraising secular and religious gender politics in Iran. In J. E. Turpin, \& L. A. Lorentzen (Eds.), The Gendered New World Order: Militarism, Development, and the Environment (pp. 113-126). Routledge.

Sedghi, H. (2007). Women and politics in Iran: Veiling, unveiling, and reveiling. Cambridge University Press. https://doi.org/10.1017/CBO9780511510380

Shahidian, H. (1996). Iranian exiles and sexual politics: Issues of gender relations and identity. Journal of Refugee Studies, 9(1), 43-72.

Stromquist, N. P. (1995). Romancing the State: Gender and power in education . Comparative Education Review, 39(4), 423-454. 
St. Pierre, E. A., \& Pillow, W. S. (Eds.). (2000). Working the ruins: Feminist poststructural theory and methods in education. New York: Routledge. https://doi.org/10.4324/9780203902257

Stone, A. (2004). From political to realist essentialism:.reading Luce Irigary. Feminist Theory. 5(1), 5-23. https://doi.org/10.1177/1464700104040810

Tabari, A., \& Yeganeh, N. (1982). In the shadow of Islam: Women's movement in Iran. London: Zed Books.

Talebinezhad, M. R., \& Aliakbari, M. (2002). Evaluation and justification of a paradigm shift in the current ELT models in Iran. Linguistik online, 10(1), Retrieved September 20, 2002 from http://www.linguistikonline.de/10_02/talebinezhadaliakbari.html

Talebinejad, M. R., \& Sadeghi Beniss, A. R. (2005). Non-academic L2 Users: A neglected research pool in ELT in Iran. Linguistik Online. http://www.linguistik-online.de/25_05/talebinezhadBeniss.pdf

Tamboukou, M. (2000). The paradox of being a woman teacher. Gender and Education, 12(4), 463-478. https://doi.org/10.1080/09540250020004108

Taylor, S. J., \& Bogdan, R. (1998). Introduction to qualitative research methods: A guidebook and resource. New York: Wiley.

Tohidi, N. (1991). Gender and Islamic fundamentalism: Feminist politics in Iran, In C. T. Mohanty, A. Russo, \& L.Torres (Eds.), Third World Women and the Politics of Feminism (pp. 251-267). Bloomington: Indiana University Press.

Tremayne, S. (2006). Modernity and early marriage in Iran: A view from within. Journal of Middle East Women's Studies. 2(1), 65-94. https://doi.org/10.1353/jmw.2006.0010

Tsui, A. B. M. (2007). Complexities of identity formation: A narrative inquiry of an EFL teacher. TESOL Quarterly, 41(4), 657-680. https://doi.org/10.1002/j.1545-7249.2007.tb00098.x

Varghese, M., Morgan, B., Johnston, B., \& Johnson, K. A. (2005). Theorizing language teacher identity: Three perspectives and beyond. Journal of Language, Identity, and Education, 4(1), 21-44. https://doi.org/ 10.1207/s15327701jlie0401_2

Walker, M. (1998). Academic identities: Women on a South African landscape. British Journal of Sociology of Education, 19(3), 335-354. https://doi.org/10.1080/0142569980190304

Walkerdine, V. (1989). Femininity as performance. Oxford Review of Education, 15(3), 267-279. https://doi.org/10.1080/0305498890150307

Weatherall, A. (2002). Gender, language and discourse. New York, Routledge.

Hurst, C., E. (2007). Social inequality. Boston: Pearson Education.

Weber, C. (2008). Between Nationalism and Feminism: The Eastern women's congresses of 
1930 and 1932. Journal of Middle East Women's Studies, 4(1), 83-106. https://doi.org/10.1353/jmw.2008.0007

Weedon, C. (1987). Feminist practice and poststructuralist theory. Oxford, Blackwell.

Weedon, C. (1999). Feminism, theory and the politics of difference, Oxford, Wiley-Blackwell.

Weitz, R. (Ed.). (2003). The politics of women's bodies: Sexuality, appearance, and behavior. New York: Oxford University Press.

Yeganeh, N. (1993). Women, nationalism, and Islam in contemporary political discourse in Iran. Feminist Review, 44, 3-18. https://doi.org/10.2307/1395192

\section{Copyright Disclaimer}

Copyright for this article is retained by the author(s), with first publication rights granted to the journal.

This is an open-access article distributed under the terms and conditions of the Creative Commons Attribution license (http://creativecommons.org/licenses/by/3.0/). 